\title{
Pendimethalin Residues from Weed Management in Dry Bean Can Cause Injury in Autumn Seeded Winter Wheat
}

\author{
Nader Soltani*, Christy Shropshire, Peter H. Sikkema \\ University of Guelph, Ridgetown Campus, Ridgetown, Canada \\ Email: soltanin@uoguelph.ca
}

Received 16 December 2014; accepted 10 January 2015; published 24 January 2015

Copyright (C) 2015 by authors and Scientific Research Publishing Inc.

This work is licensed under the Creative Commons Attribution International License (CC BY).

http://creativecommons.org/licenses/by/4.0/

(c) (i) Open Access

\begin{abstract}
There is little information on effect of pendimethalin residues in the soil used for weed management in dry bean, on winter wheat seeded 3 to 4 months after application in Ontario. A total of four field experiments were conducted over a four-year period (2008-2011) in Ontario to evaluate the effect of pendimethalin residues on winter wheat injury and yield grown in rotation with dry bean. Pendimethalin, applied PPI in dry bean, at 1080 and $2160 \mathrm{~g}^{\text {ai ha }} \mathrm{h}^{-1}$ caused $1 \%$ to $3 \%$ injury and $4 \%$ to $9 \%$ winter wheat injury evaluated 1 and 4 weeks after emergence (WAE) in the fall and on approximately the first of May, June and July of the following year. Pendimethalin applied PPI in the spring at $1 \mathrm{X}$ or $2 \mathrm{X}$ manufacturer's recommended rate $\left(1080\right.$ or $\left.2160 \mathrm{~g}^{\mathrm{ai} \mathrm{ha}} \mathrm{ha}^{-1}\right)$ in dry bean caused no adverse effect on the winter wheat height evaluated in July of the following year and no adverse effect on maturity at harvest. Pendimethalin applied PPI at $1080 \mathrm{~g}^{\text {ai ha }} \mathrm{ha}^{-1}$ in dry bean in the spring caused no adverse effect on winter wheat yield, but pendimethalin applied at $2160 \mathrm{~g}^{\text {ai }} \mathrm{ha}^{-1}$ rate caused a $4 \%$ reduction in yield of winter wheat. Based on this study, pendimethalin applied PPI at $2160 \mathrm{~g}^{\text {ai }} \mathrm{ha}^{-1}$ has potential to cause injury and yield reduction in winter wheat grown in rotation with dry bean under Ontario environmental conditions.
\end{abstract}

\section{Keywords}

Carry over, Injury, Height, Herbicide, Residual, Tolerance, Yield

\section{Introduction}

Dry bean (Phaseolus vulgaris L.), winter wheat (Triticumaestivum L.), corn (Zea mays L.) and soybean (Glycine

"Corresponding author.

How to cite this paper: Soltani, N., Shropshire, C. and Sikkema, P.H. (2015) Pendimethalin Residues from Weed Management in Dry Bean Can Cause Injury in Autumn Seeded Winter Wheat. Agricultural Sciences, 6, 159-163. 
max L.) are frequently grown in rotation in southwestern Ontario. Residual activity of herbicides should be considered when used in a diverse crop rotation. Dry bean, a short season crop that matures in 80 - 100 days, is an ideal crop to grow prior to seeding winter wheat [1]. Injury from herbicide residues needs to be considered when growing winter wheat in rotation with dry bean. Ideally, growers would like a herbicide that provides full season residual weed control but does not cause injury to the subsequent winter wheat crop seeded in the autumn of the same year.

Pendimethalin, a dinitroaniline herbicide, is a selective herbicide that controls annual grasses such as barnyardgrass (Echinochloacrusgalli (L.) Beauv.), fall panicum (Panicumdichotomiflorum Michx.), giant foxtail (Setariafaberii Herrm.), green foxtail (Setariaviridis (L.) Beauv.), yellow foxtail (Setariaglauca (L.) Beauv.), smooth crabgrass (Digitariaischaemum (Schreb) Muhl.) and large crabgrass (Digitariasanguinalis (L.) Scop). Pendimethalin also has activity on annual broadleaved weeds in Ontario such as redroot pigweed (Amaranthusretroflexus L.) and common lambsquarters (Chenopodium album L.) including acetolactate synthase and triazine-resistant biotypes [2] [3]. Pendimethalin is primarily absorbed by the emerging coleoptile of grasses and hypocotyl/epicotyl of broadleaf weeds. Beyond the germination stage pendimethalin is also taken up by the roots where the chemical inhibits cell division and cell elongation. Susceptible plants die shortly after germination or following emergence from the soil [3]. Pendimethalin persistence in soil is dependent on environmental conditions [3]. Pendimethalin is immobile and is strongly bound to the organic matter and clay in the soil [3]. Pendimethalin dissipates from soil mainly by microbial degradation [4] [5]. Kulshrestha et al. [6] studying the effect of long-term application of pendimethalin at $1500 \mathrm{~g}$ ai ha ${ }^{-1}$ in a corn-wheat rotation over five consecutive years in the same plots found that harvest-time residues of the herbicide decreased gradually over the years and at the end of five years less than 3\% of applied pendimethalin was recovered from soil compared to $18 \%$ in the first year.

Pendimethalin is currently registered in lima bean, snap bean and adzuki bean in Ontario. Pendimethalin is also being considered for registration in additional market classes of dry bean as earlier studies have shown that pendimethalin applied PPI or PRE at the proposed rate of $1080 \mathrm{~g}_{\text {ai ha }}{ }^{-1}$ has an adequate margin of crop safety for use in black, cranberry, kidney, and white bean under Ontario environmental conditions [7] [8]. Availability of pendimethalin would provide Ontario dry bean producers with a new herbicide for the control of annual grasses and small seeded broadleaved weeds. Using pendimethalin in a diversified, integrated weed management program could also help reduce the selection intensity for herbicide resistant weeds. Dry bean growers often seed winter wheat immediately following dry bean harvest. To our knowledge, there is no published study that addresses the effect of pendimethalin residues in the soil on winter wheat seeded in the same field season in Ontario.

The objective of this study was to evaluate the effect of pendimethalin residues on winter wheat injury, height, maturity and yield seeded following dry bean under Ontario environmental conditions.

\section{Materials and Methods}

Four field experiments were established at the Huron Research Station, Exeter, Ontario in the autumn of 2008 to 2010, with winter wheat harvested in the summer of 2009 to 2011. The soil characteristics are listed in Table 1.

Dry bean was established using conventional tillage and winter wheat was direct seeded (no-tillage) immediately after dry bean harvest in the autumn. Experiments were arranged in a completely randomized block design with four replications. Treatments included preplant applications of pendimethalin at 0, 1080 and $2160 \mathrm{~g}$ ai ha $^{-1}$ applied preplant incorporated (PPI). The PPI application of pendimethalin was made to the soil surface one day before seeding dry bean and was immediately incorporated into the soil to a depth of $5 \mathrm{~cm}$ with two passes (in opposite directions) of an S-tine cultivator with rolling basket harrows. Plots were $3 \mathrm{~m}$ wide (4 rows spaced $0.75 \mathrm{~m}$ apart) and $10 \mathrm{~m}$ long. Dry bean was seeded to a depth of $5 \mathrm{~cm}$ in late May to early June. In late August to early September of each year after dry bean was harvested, the plots were then seeded with Pioneer "25R47”, a commonly grown soft, red winter wheat cultivar in Ontario, in rows spaced $18 \mathrm{~cm}$ apart. At all locations, winter wheat was seeded $3 \mathrm{~cm}$ deep using a double disk seeder at a rate of $170 \mathrm{~kg} \cdot \mathrm{ha}^{-1}$.

Herbicide treatments were applied using a $\mathrm{CO}_{2}$-pressurized backpack sprayer calibrated to deliver $200 \mathrm{~L} \cdot \mathrm{ha}^{-1}$ at $240 \mathrm{kPa}$. The boom was $2.5 \mathrm{~m}$ long with six ultra-low drift nozzles (ULD120-02, Hypro, New Brighton, MN) spaced $50 \mathrm{~cm}$ apart. Plots were maintained weed free by cultivation and hand hoeing as required to eliminate the confounding effect of weed interference.

Winter wheat injury was visually estimated on a scale of 0 (no injury) to $100 \%$ (complete plant death) at 1 and 4 weeks after crop emergence (WAE) and on approximately the first of May, June and July of the following 
Table 1. Soil characteristics at Exeter and Ridgetown, ON, in 2008-2010.

\begin{tabular}{cccccccc}
\hline Location & Year & Sand (\%) & Silt (\%) & Clay (\%) & OM $^{\mathrm{a}}(\%)$ & $\mathrm{pH}$ & $\mathrm{CEC}$ \\
\hline Exeter & 2008 & 33 & 35 & 32 & 3.4 & 7.9 & 31 \\
Exeter & 2009 & 38 & 41 & 21 & 3.7 & 7.8 & 31 \\
Exeter & 2010 & 36 & 39 & 25 & 3.6 & 7.8 & 32 \\
Exeter & 2010 & 35 & 43 & 22 & 3.8 & 7.7 & 28 \\
\hline
\end{tabular}

${ }^{a} \mathrm{OM}$ : Organic Matter.

growing season. Winter wheat height was measured for 10 plants per plot in mid-July and averaged. Winter wheat was harvested from each plot with a small plot combine and seed moisture content and weight were recorded. Winter wheat seed yields were adjusted to $14 \%$ moisture.

Data were analyzed using PROC MIXED in SAS 9.2. Herbicide treatment was considered a fixed effect, while environment, the interaction between environment and herbicide treatment, and replicate nested within environment were considered random effects. Significance of the fixed effect was tested using F-tests and random effects were tested using a Z-test of the variance estimate. Environments were combined for all variables. The UNIVARIATE procedure was used to test data for normality and homogeneity of variance. For all injury ratings, the untreated check (assigned a value of zero) was excluded from the analysis. However, all values were compared independently to zero to evaluate treatment differences with the untreated check. To satisfy the assumptions of the variance analyses, injury 1 and 4 WAE, on approximately the first of May and June were square root transformed; winter wheat seed moisture content at harvest was log transformed. Treatment comparisons were made using Fisher's Protected LSD at a level of $\mathrm{P}<0.05$. Data analyzed on the transformed scale were converted back to the original scale for presentation of results.

\section{Results and Discussion}

Statistical analysis indicated that environment by treatment interaction was not significant therefore, four datasets were analyzed together. Crop injury symptoms from pendimethalin included slightly reduced growth with a slight purplish hue.

\subsection{Winter Wheat Injury}

Pendimethalin applied PPI at $1080 \mathrm{~g}_{\text {ai }} \mathrm{ha}^{-1}$ in dry bean in the spring caused $1 \%$ to $3 \%$ visual injury in winter wheat evaluated 1 and 4 WAE in the fall and on approximately the first of May, June and July of the following year (Table 2). However, pendimethalin applied PPI at twice the manufacturer's recommended rate (2160 g ai $\mathrm{ha}^{-1}$ ) in dry bean in the spring caused $4 \%$ to $9 \%$ injury in winter wheat evaluated 1 and 4 WAE in the fall and $4 \%$ to 6\% injury on approximately the first of May, June and July of the following year (Table 2). In other studies, pendimethalin applied at $2240 \mathrm{~g}_{\text {ai ha }}{ }^{-1}$ to lentil in the spring reduced winter wheat biomass $35 \%$ to $51 \%$ [9]. Pendimethalin at $1120 \mathrm{~g}_{\text {ai ha }}{ }^{-1}$ plus imazethapyr at $106 \mathrm{~g} \mathrm{ai} \mathrm{ha}^{-1}$ also reduced wheat biomass as much as $24 \%$ at some sites [9]. Wicks et al. [10] found 3\% to 55\% injury in winter wheat with pendimethalin (2800 $\mathrm{g}^{\text {ai ha }}{ }^{-1}$ ) plus metribuzin (300 $\mathrm{g}_{\text {ai ha }}{ }^{-1}$ ) when applied within the same growing season to 25 cultivars of winter wheat.

\subsection{Winter Wheat Height}

Pendimethalin applied PPI in the spring at $1 \mathrm{X}$ or $2 \mathrm{X}$ manufacturer's recommended rate (1080 or $2160 \mathrm{~g}^{\mathrm{ai}} \mathrm{ha}^{-1}$ ) in dry bean caused no adverse effect on the winter wheat height evaluated in July of the following growing season (Table 2). In other studies, Miller [1] found that pendimethalin applied at $1200 \mathrm{~g} \mathrm{ai} \mathrm{ha}^{-1}$ to pea in the spring had no significant effect on winter wheat biomass in the following year at harvest time. Other dinitroaniline herbicides such as trifluralin were also shown to have no significant effect on winter wheat biomass when applied in the previous year to peas [1].

\subsection{Yield and Seed Moisture}

Pendimethalin applied PPI at $1080 \mathrm{~g}$ ai ha ${ }^{-1}$ in dry bean in the spring caused no adverse effect on winter wheat 
Table 2. Values for percent injury, height, seed moisture content and yield of winter wheat planted after dry bean treated with pendimethalin PPI. Means followed by the same letter within a column are not significantly different according to Fisher's Protected LSD at $\mathrm{P}<0.05^{\mathrm{a}}$.

\begin{tabular}{|c|c|c|c|c|c|c|c|c|c|}
\hline \multicolumn{10}{|c|}{ Injury } \\
\hline Treatment & Rate & $1 \mathrm{WAE}$ & 4 WAE & May & June & July & Height & Moisture & Yield \\
\hline & $\mathrm{g}$ ai ha ${ }^{-1}$ & & & & & & $\mathrm{~cm}$ & $\%$ & MT ha $^{-1}$ \\
\hline Untreated & 0 & $0 \mathrm{a}$ & $0 \mathrm{a}$ & $0 \mathrm{a}$ & $0 \mathrm{a}$ & 0 & 88 & 14.8 & $6.90 \mathrm{a}$ \\
\hline Pendimethalin & 1080 & $1 \mathrm{a}$ & $3 a b$ & $2 \mathrm{~b}$ & $1 \mathrm{ab}$ & 2 & 87 & 14.8 & $6.86 \mathrm{ab}$ \\
\hline Pendimethalin & 2160 & $4 \mathrm{a}$ & $9 \mathrm{~b}$ & $6 \mathrm{~b}$ & $4 \mathrm{~b}$ & 5 & 86 & 15.0 & $6.65 \mathrm{~b}$ \\
\hline SE & & 1 & 2 & 1 & 1 & 1 & 1 & 0.5 & 0.07 \\
\hline
\end{tabular}

${ }^{\mathrm{a} W A E}$ : Weeks after Wheat Emergence; PPI: Preplant Incorportated.

yield and seed moisture content at harvest time (Table 2). However, pendimethalin applied PPI at twice the manufacturer's recommended rate (2160 $\mathrm{g}$ ai ha $\left.{ }^{-1}\right)$ in dry bean in the spring caused a $4 \%$ reduction in yield of winter wheat at harvest time (Table 2). There was no effect on winter wheat seed moisture content at the harvest time with pendimethalin applied PPI at twice the manufacturer's recommended rate (2160 $\mathrm{g}$ ai ha $\left.{ }^{-1}\right)$. In other studies, pendimethalin applied at $2240 \mathrm{~g}_{\text {ai ha }}{ }^{-1}$ to lentils in the spring reduced winter wheat grain yield $11 \%$ to $17 \%$ at the harvest time in the following year [9]. Wicks et al. [10] comparing 25 cultivars of winter wheat found as much as $25 \%$ reduction in grain yield of some winter wheat cultivars with pendimethalin ( $2800 \mathrm{~g}$ ai $\mathrm{ha}^{-1}$ ) plus metribuzin ( $300 \mathrm{~g}_{\text {ai }} \mathrm{ha}^{-1}$ ) when applied within the same growing season.

\section{Conclusion}

Based on this study, Pendimethalin applied PPI at $1080 \mathrm{~g}$ ai ha $^{-1}$ in dry bean in the spring causes minimal injury in winter wheat evaluated 1 and 4 WAE in the fall and on approximately the first of May, June and July of the following year. In addition, there was no effect on winter wheat height, maturity (seed moisture content) and yield. However, pendimethalin applied PPI at $2160 \mathrm{~g}$ ai ha $^{-1}$ in dry bean in the spring causes significant injury in winter wheat evaluated 1 and 4 WAE in the fall and on approximately the first of May, June and July of the following year and can reduce yield as much as $4 \%$. Based on these results there is the potential for winter wheat injury and yield loss in areas where there is spray overlaps of pendimethalin at the manufacturer's rate of $1080 \mathrm{~g}$ ai ha ${ }^{-1}$.

\section{Acknowledgements}

The authors would like to acknowledge Todd Cowan for his expertise and technical assistance in these studies. Funding for this project was provided in part by the Grain Farmers of Ontario (GFO) and the GF2 program of the Agricultural Adaptation Council.

\section{References}

[1] Miller, T.W. (2009) Effect of Several Herbicides on Green Pea (Pisumsativum) and Subsequent Crops. Weed Technology, 17, 731-737. http://dx.doi.org/10.1614/WT02-127

[2] Ontario Ministry of Agriculture, Food, and Rural Affairs (OMAFRA) (2014) Guide to Weed Control. Ontario Ministry of Agriculture, Food, and Rural Affairs, Toronto.

[3] Shaner, D.L. (2014) Herbicide Handbook.10th Edition, Champaign.

[4] Barua, A.S., Saha, J., Chaudhuri, S., Chowdhury, A. and Adityachaudhury, N. (1990) Degradation of Pendimethalinby Soil Fungi. Pesticide Science, 29, 419-425. http://dx.doi.org/10.1002/ps.2780290406

[5] Singh, S.B. and Kulshrestha, G. (1991) Microbial Degradation of Pendimethalin. Journal of Environmental Science and Health Part B, 26, 309-321. http://dx.doi.org/10.1080/03601239109372737

[6] Kulshrestha, G., Singh, S.B., Lal, S.P. and Yaduraju, N.T. (2000) Effect of Long-Term Field Application of Pendimethalin: Enhanced Degradation in Soil. Pest Management Science, 56, 202-206. http://dx.doi.org/10.1002/(SICI)1526-4998(200002)56:2<202::AID-PS97>3.0.CO;2-C

[7] Soltani, N., Nurse, R.E., Shropshire, C. and Sikkema, P.H. (2013) Response of Dry Beanto Pendimethalin Applied Preplant Incorporated or Preemergence. African Journal of Agricultural Research, 8, 4827-4832. 
[8] Soltani, N., Nurse, R.E. and Sikkema, P.H. (2013) Tolerance of White and Adzuki Bean to Pendimethalinplus Reduced Doses of Imazethapyr. African Journal of Plant Science, 7, 143-148. http://dx.doi.org/10.5897/AJPS12.0717

[9] Hanson, B.D. and Thill, D.C. (2001) Effects of Imazethapyrand Pendimethalinon Lentil (Lens culinaris), Pea (Pisumsativum), and a Subsequent Winter Wheat (Triticumaestivum) Crop. Weed Technology, 15, 190-194. http://dx.doi.org/10.1614/0890-037X(2001)015[0190:EOIAPO]2.0.CO;2

[10] Wicks, G.A., Nordquist, P.T., Hanson, G.E. and Schmidt, J.W. (1987) Response of Winter Wheat (Triticumaestivum) to Herbicides. Weed Science, 35, 259-262. 
Scientific Research Publishing (SCIRP) is one of the largest Open Access journal publishers. It is currently publishing more than 200 open access, online, peer-reviewed journals covering a wide range of academic disciplines. SCIRP serves the worldwide academic communities and contributes to the progress and application of science with its publication.

Other selected journals from SCIRP are listed as below. Submit your manuscript to us via either submit@scirp.org or Online Submission Portal.
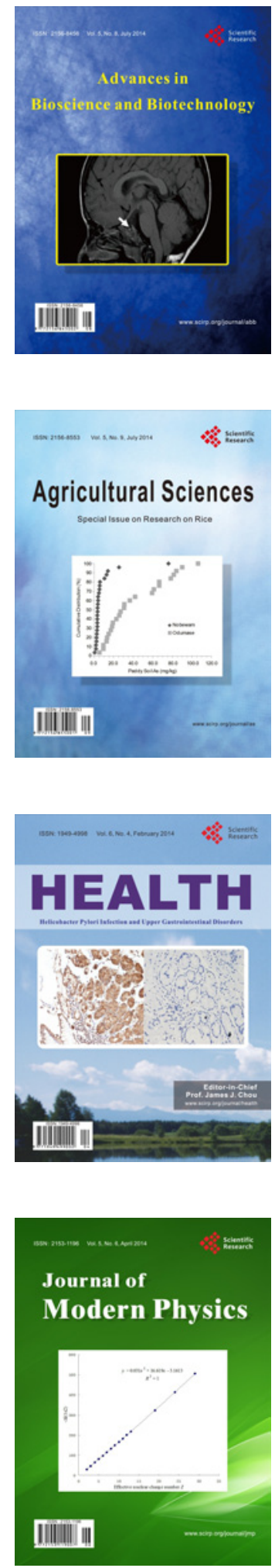
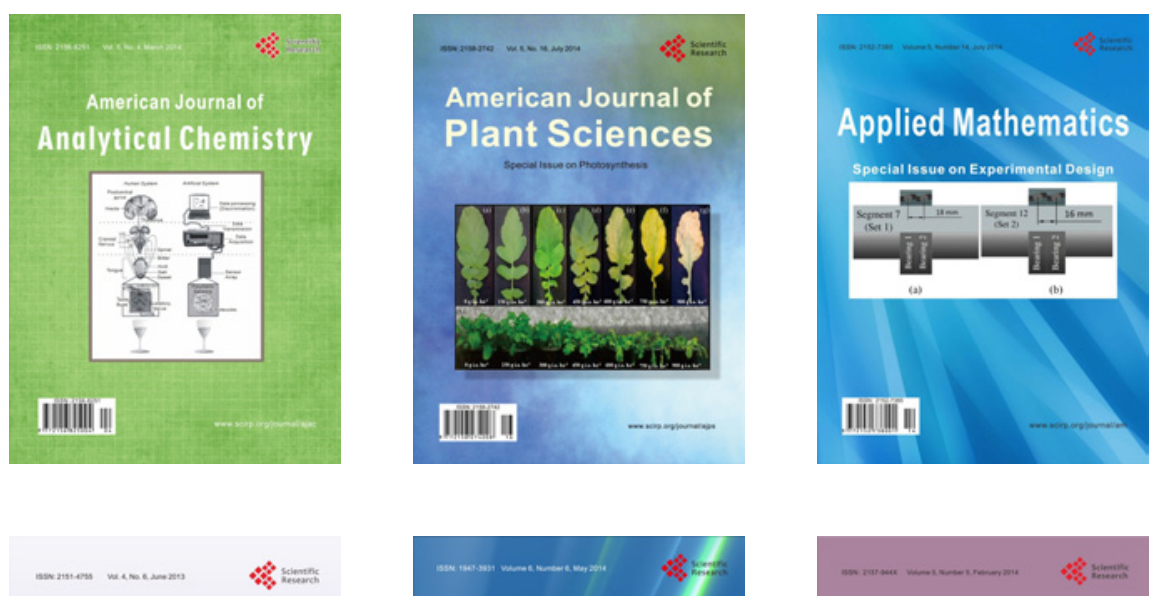

Creative Education
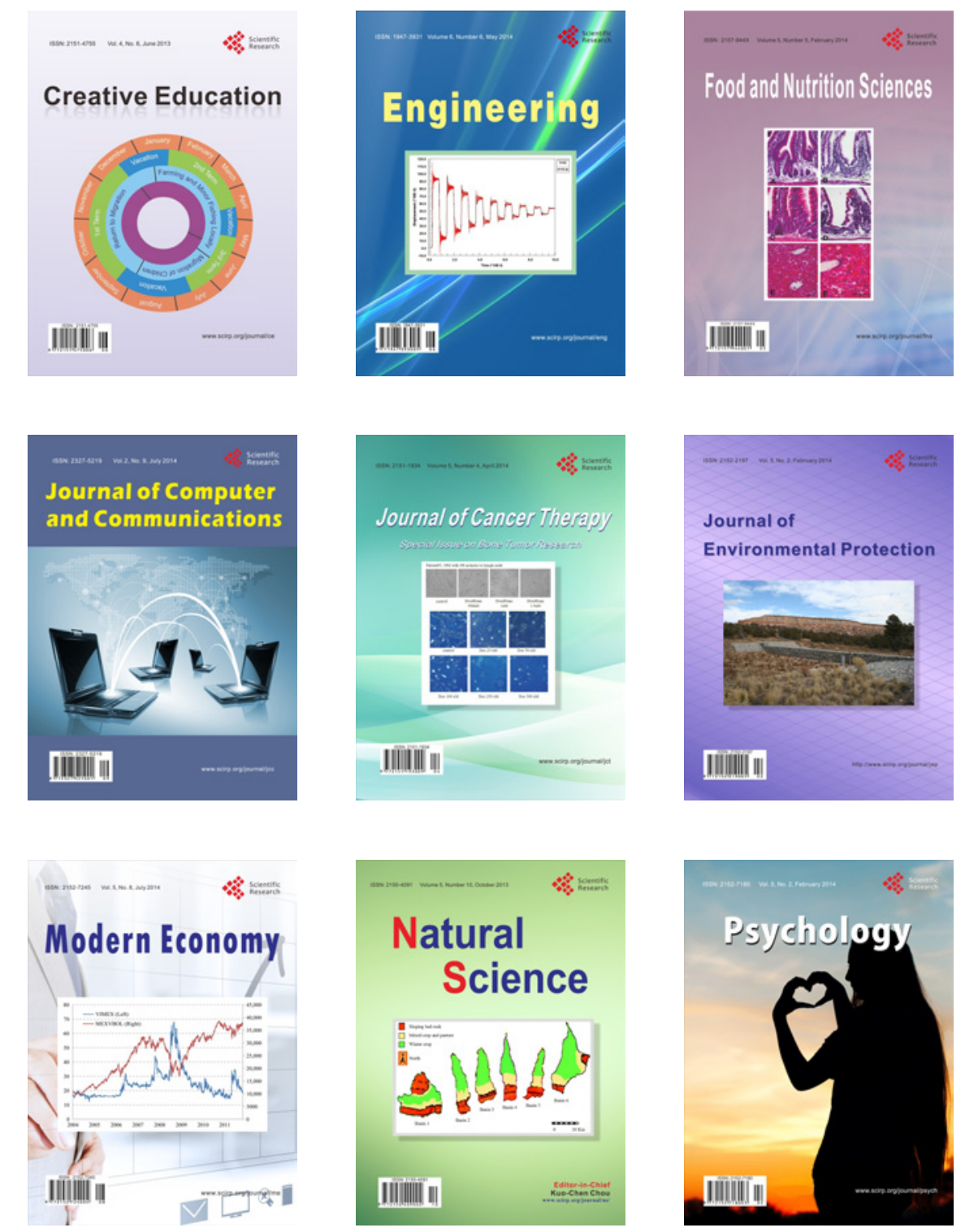